\title{
Geology and Design of Major Spent Fuel Repositories
}

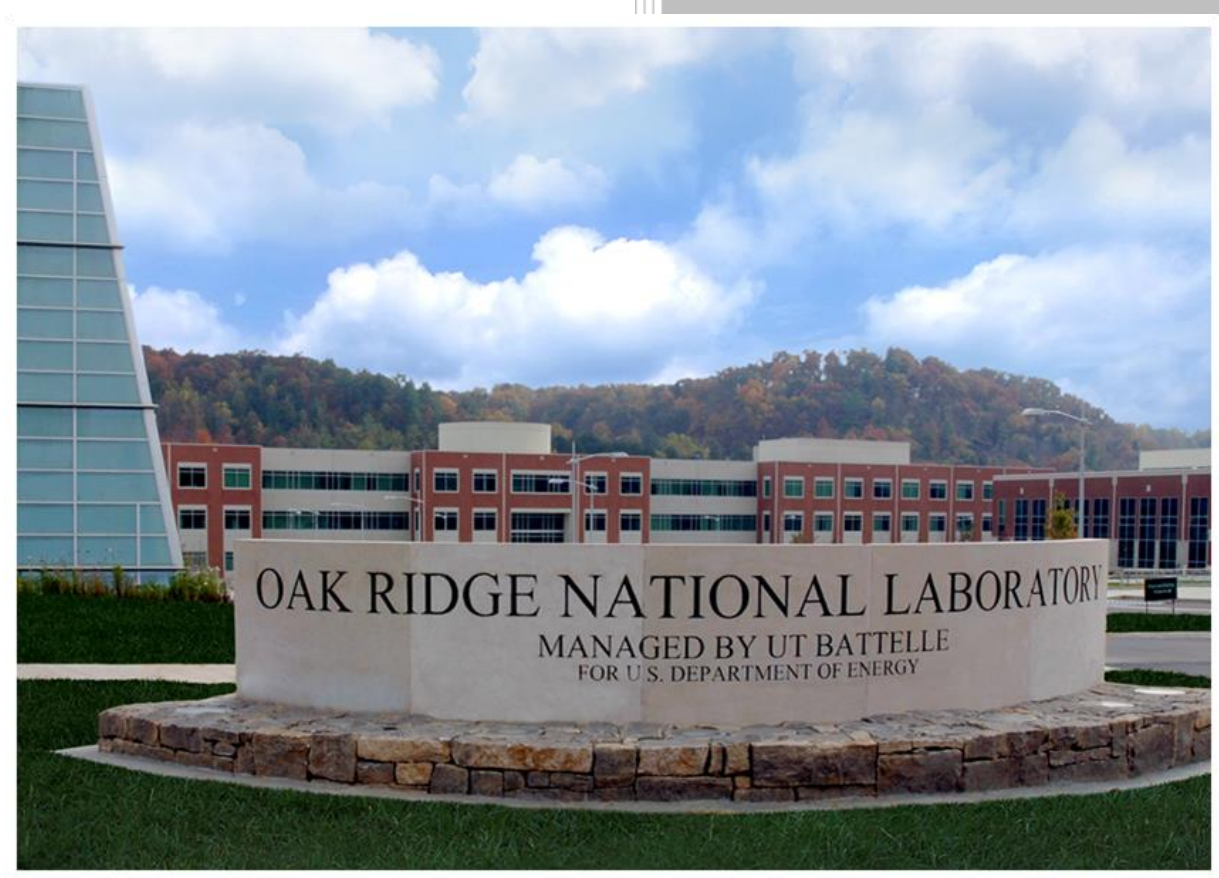

\section{Approved for public release.} Distribution is unlimited.
Matthew Larson

Will Ray

Scott Stewart

Susan Smith

Alexandra Hackett

Nicholas Burchfield

Brad Stinson

November 2020 


\title{
DOCUMENT AVAILABILITY
}

Reports produced after January 1, 1996, are generally available free via US Department of Energy (DOE) SciTech Connect.

Website www.osti.gov

Reports produced before January 1, 1996, may be purchased by members of the public from the following source:

\author{
National Technical Information Service \\ 5285 Port Royal Road \\ Springfield, VA 22161 \\ Telephone 703-605-6000 (1-800-553-6847) \\ TDD 703-487-4639 \\ Fax 703-605-6900 \\ E-mail info@ntis.gov \\ Website http://classic.ntis.gov/
}

Reports are available to DOE employees, DOE contractors, Energy Technology Data Exchange representatives, and International Nuclear Information System representatives from the following source:

Office of Scientific and Technical Information

PO Box 62

Oak Ridge, TN 37831

Telephone 865-576-8401

Fax 865-576-5728

E-mail reports@osti.gov

Website http://www.osti.gov/contact.html

This report was prepared as an account of work sponsored by an agency of the United States Government. Neither the United States Government nor any agency thereof, nor any of their employees, makes any warranty, express or implied, or assumes any legal liability or responsibility for the accuracy, completeness, or usefulness of any information, apparatus, product, or process disclosed, or represents that its use would not infringe privately owned rights. Reference herein to any specific commercial product, process, or service by trade name, trademark, manufacturer, or otherwise, does not necessarily constitute or imply its endorsement, recommendation, or favoring by the United States Government or any agency thereof. The views and opinions of authors expressed herein do not necessarily state or reflect those of the United States Government or any agency thereof. 
Geospatial Science and Human Security Division

\title{
GEOLOGY AND DESIGN OF MAJOR SPENT FUEL REPOSITORIES
}

\author{
Matthew Larson \\ Will Ray \\ Scott Stewart \\ Susan Smith \\ Alexandra Hackett \\ Nicholas Burchfield \\ Brad Stinson
}

Date Published: November 2020

Prepared by OAK RIDGE NATIONAL LABORATORY

Oak Ridge, TN 37831-6283

managed by

UT-BATTELLE, LLC

for the

US DEPARTMENT OF ENERGY

under contract DE-AC05-00OR22725 


\section{TABLE OF CONTENTS}

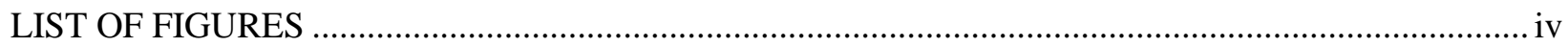

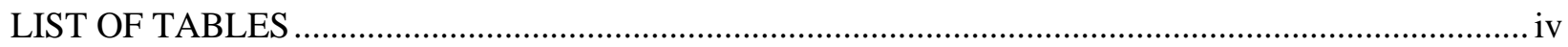

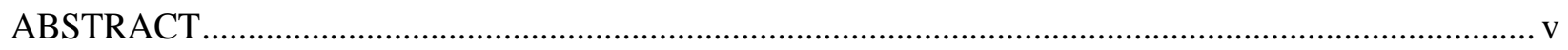

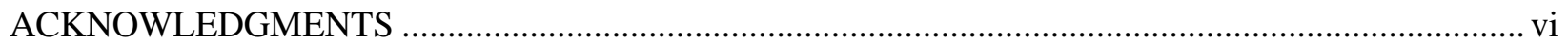

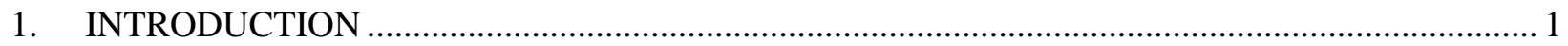

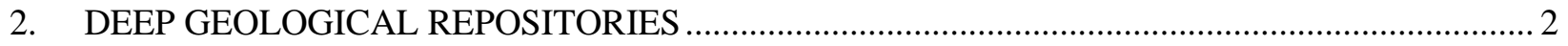

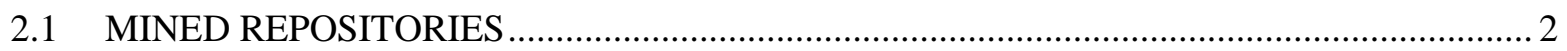

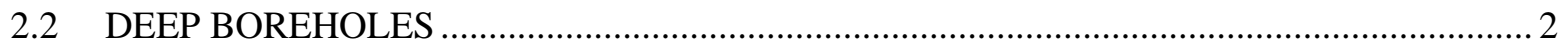

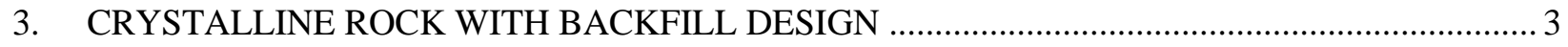

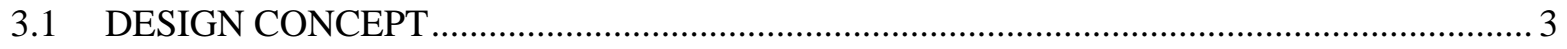

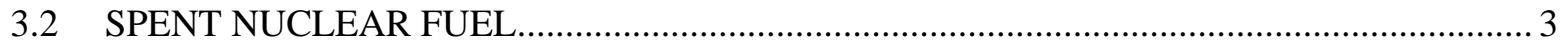

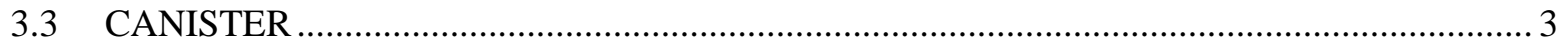

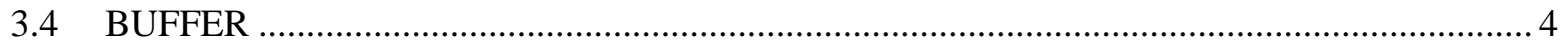

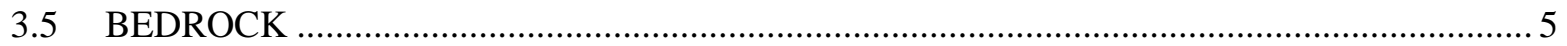

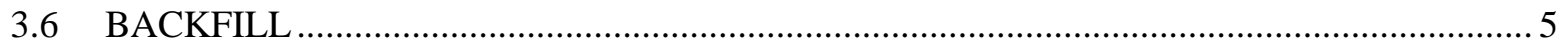

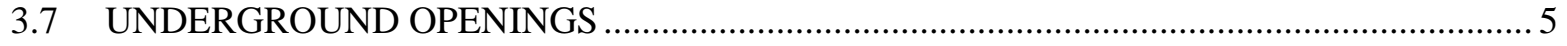

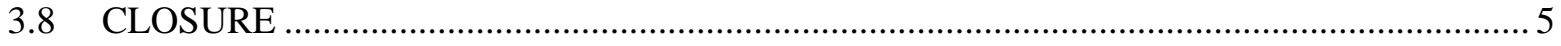

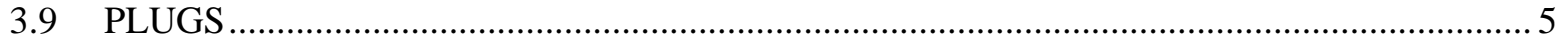

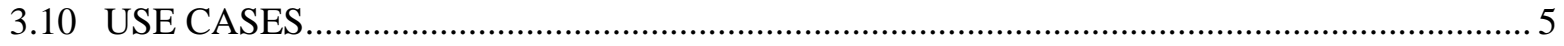

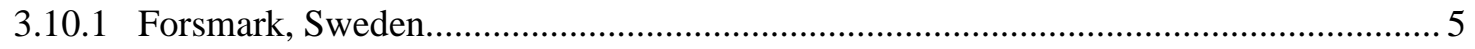

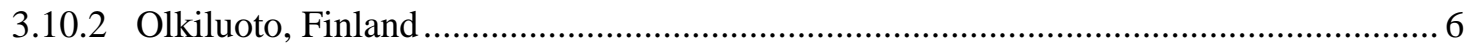

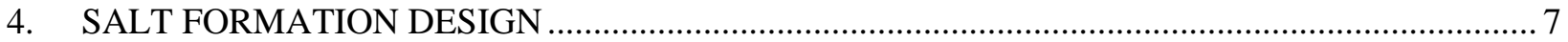

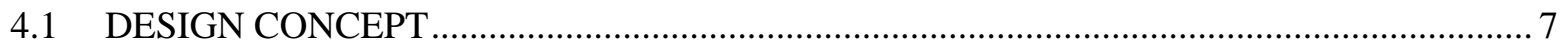

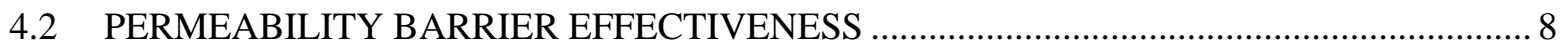

4.3 BRINE/WATER MOBILITY IN THE REPOSITORY NEAR FIELD ................................. 8

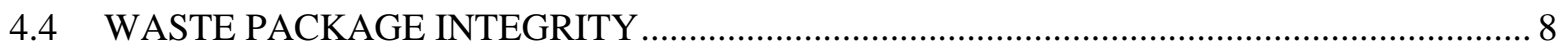

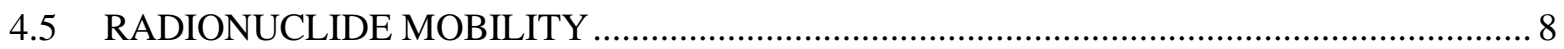

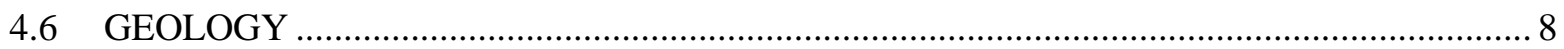

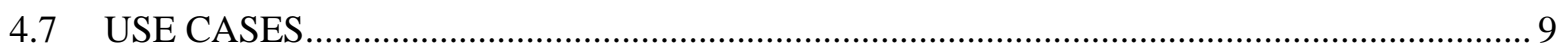

4.7.1 Waste Isolation Pilot Plant (WIPP), New Mexico, United States................................ 9

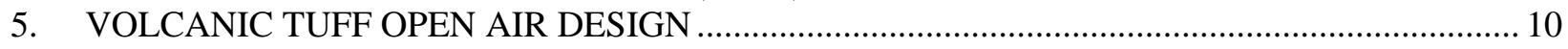

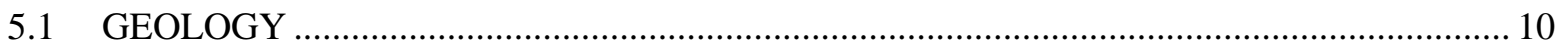

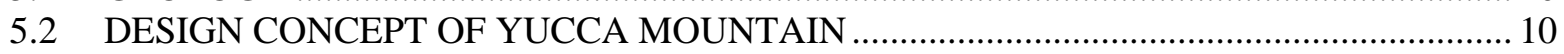

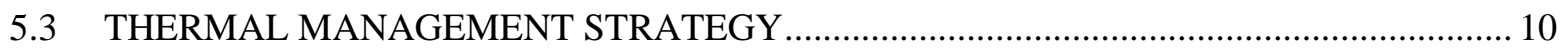

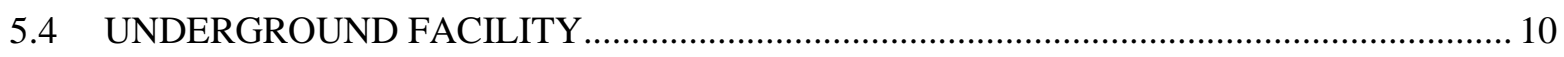

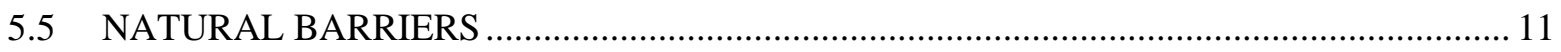

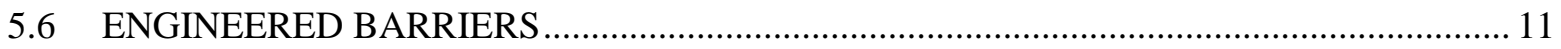

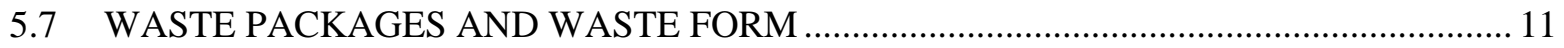

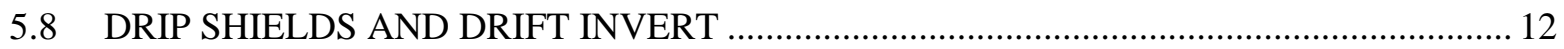

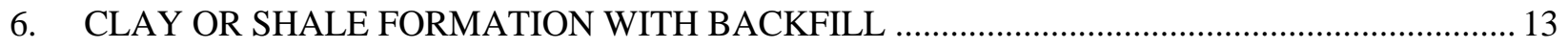

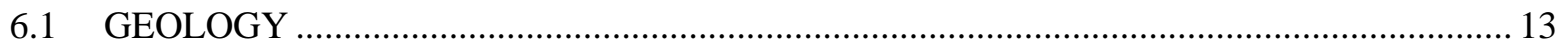

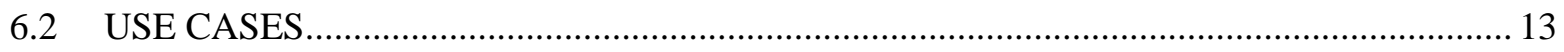

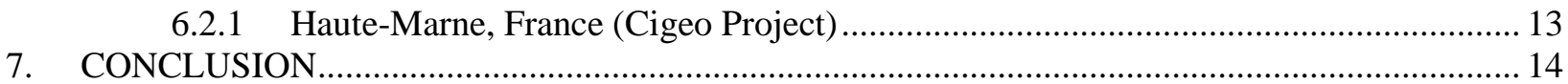

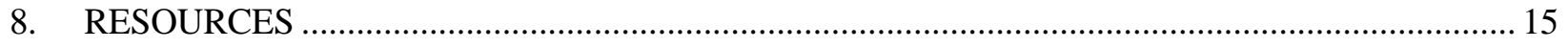




\section{LIST OF FIGURES}

Figure 3-1: Crystalline rock with backfill design (e.g., KBS-3) showing one of the many tunnels that consist of the following: canister containing spent nuclear fuel; buffer, which consists primarily of bentonite, a montmorillonite clay; and backfill, which consists of compacted bentonite blocks with surrounding clay pellets.

Figure 3-2: Example of fuel rod assembly, canister insert, and copper protective shell of the spent fuel package being deposited.

Figure 4-1: Typical tunnel within a spent fuel repository located in a salt formation.

Figure 5-1: Volcanic tuff open air design (e.g., Yucca Mountain) where canisters containing spent fuel are aligned end-to-end on the drift floor.

\section{LIST OF TABLES}

Table 1-1: Commonly accepted radioactive waste disposal options...................................................... 1

Table 1-2: Favorable and unfavorable properties of potential host media relevant for disposal. * .............. 1

Table 3-1: Major rock groups with simplified rock units and rock types at Forsmark............................. 6 


\begin{abstract}
This report summarizes the geology and design concepts of four major spent fuel repositories from around the world. The crystalline rock with bentonite backfill is currently implemented in Finland with another repository being constructed in Sweden. The salt formation design focuses on the Waste Isolation Pilot Plant (WIPP) repository in the United States. The volcanic tuff open air design is based on the Yucca Mountain location. The volcanic tuff open air design at Yucca Mountain is only a concept as this repository has not been approved for operations. The last spent fuel repository design, clay/shale formation with backfill, focuses on the Cigeo Project in France, which is also pending.
\end{abstract}




\section{ACKNOWLEDGMENTS}

The authors would like to acknowledge and thank Dr. Christopher Ramos, the Safeguards Program Manager for the US Department of Energy (DOE) National Nuclear Security Administration (NNSA) Office of Defense Nuclear Nonproliferation Research and Development (DNN R\&D) for supporting this work and his technical leadership. We are also grateful for technical input and guidance provided by Warnick Kernan, DNN R\&D Safeguards Technical Advisor. 


\section{INTRODUCTION}

International Atomic Energy Agency (IAEA) member states are discussing whether and to what degree reversibility and retrievability can be built into radioactive waste storage facilities (IAEA 2009). The notion of retrievability is to increase the level of flexibility and to provide the ability to benefit from new technological advances in waste management (IAEA 2009). Radioactive waste can be categorized, based on the radionuclide content, the longevity of the radiological hazard presented, and the activity level, typically as low- and intermediate-level wastes (both short and long lived) and high-level wastes (LLW, ILW, HLW) (IAEA 2009). Geologically, radioactive waste can generally be stored in near-surface or deep geological disposal sites, as summarized in Table 1-1. Geological disposal is based upon the isolation of the waste in locations that are determined to be stable over long periods of time. The main host rocks for storage are typically crystalline igneous and volcanic rocks (e.g., intrusive igneous), argillaceous clay, indurated clay and plastic clay-rich rocks, as well as salt formations (IAEA 2009; ChinFu et al. 2004), each having its own unique properties (Table 1-2). The choice of host rock is determined by the availability of appropriate geological formations and by suitable thickness (IAEA 2009). Location and host rock composition and characteristics, as well as type of waste, all determine the type of radioactive and nuclear waste storage method.

Table 1-1: Commonly accepted radioactive waste disposal options.

\begin{tabular}{|l|l|l|}
\hline \multicolumn{1}{|c|}{ Option } & \multicolumn{1}{|c|}{ Suitable Waste Type } & \multicolumn{1}{c|}{ Repository Depth below Surface } \\
\hline $\begin{array}{l}\text { Near-surface disposal } \\
\text { At ground level or in } \\
\text { caverns below ground level }\end{array}$ & LLW and short-lived ILW & $10 \mathrm{~s}$ of meters \\
\hline Deep geological disposal & $\begin{array}{l}\text { Long-lived ILW and HLW } \\
\text { (including used fuel) }\end{array}$ & $\begin{array}{l}250-1000 \mathrm{~m} \text { for mined repositories } \\
2000-5000 \mathrm{~m} \text { for boreholes }\end{array}$ \\
\hline
\end{tabular}

Table 1-2: Favorable and unfavorable properties of potential host media relevant for disposal.*

\begin{tabular}{|l|c|c|c|}
\hline \multicolumn{1}{|c|}{ Property } & Salt & Crystalline Rock & Argillaceous Formations \\
\hline Thermal Conductivity & High & Medium & Low \\
\hline Permeability & Very low & $\begin{array}{c}\text { Very low (unfractured) } \\
\text { Permeable (fractured) }\end{array}$ & Plastic to brittle \\
\hline Deformation Behavior** & $\begin{array}{c}\text { Visco-plastic } \\
\text { (Creep) }\end{array}$ & Brittle & Low - medium \\
\hline Strength & Medium & High & Very low \\
\hline Dissolution Behavior** & High & Very low & Very high \\
\hline Sorption Behavior** & Very low & Medium - high & \\
\hline
\end{tabular}

* Adapted from Winterle et al., 2012. Green = Favorable; Yellow = Average; Red = Unfavorable

**Does not include changes because of thermal perturbation 


\section{DEEP GEOLOGICAL REPOSITORIES}

\subsection{MINED REPOSITORIES}

Mined repositories are the most widely proposed deep geological disposal concept as they are composed of tunnels or caverns into which packaged radioactive waste would be placed. In certain circumstances, such as when wet rock is present, waste containers are then surrounded by backfill, which is typically cement, clay, or a combination of both. Waste container design and backfill material vary, depending on the type of waste and the geology of the host rock type available (World Nuclear Association 2018). Excavation of these deep geological facilities is limited to rock units that are stable without major groundwater flow and with depth of 250-1000 m.

\subsection{DEEP BOREHOLES}

This concept consists of drilling a borehole into bedrock to a depth of about $5000 \mathrm{~m}$, emplacing radioactive waste containers in the lower $40 \%$ of the borehole and sealing the upper $60 \%$ with clay (e.g., bentonite), asphalt, or concrete. Containers are separated from each other by a layer of bentonite or cement. Boreholes can be drilled in a variety of locations both on and offshore in both crystalline and sedimentary bedrock. Borehole repositories are typically considered non-retrievable. Currently, no country has plans for deep borehole repositories and therefore will not be the focus of this report. 


\section{CRYSTALLINE ROCK WITH BACKFILL DESIGN}

\subsection{DESIGN CONCEPT}

One of the most predominant and modeled crystalline rock repositories is the KBS-3 design and therefore will be the focus of this section. The KBS-3 repository concept was developed by SKB (Swedish Nuclear Fuel and Waste Management Co.) who is responsible for nuclear waste management in Sweden. A key component of the design is that it uses multiple overlapping barriers to contain the radioactive nuclear waste to ensure public safety. In KBS-3, spent nuclear fuel is encapsulated in corrosion-resistant and load-bearing canisters which are deposited in crystalline rock at a depth of 400-700 m. Deposited canisters are surrounded by a protective buffer which also prevents flowing water from contacting the canister, as shown in Figure 3-1 (SKB 2010). Tunnels throughout the bedrock required for the deposition of canisters are backfilled and closed. The KBS-3 repository consists of; the spent nuclear fuel, canister, buffer, bedrock, backfill in deposition tunnels, underground openings, closure, and plugs.

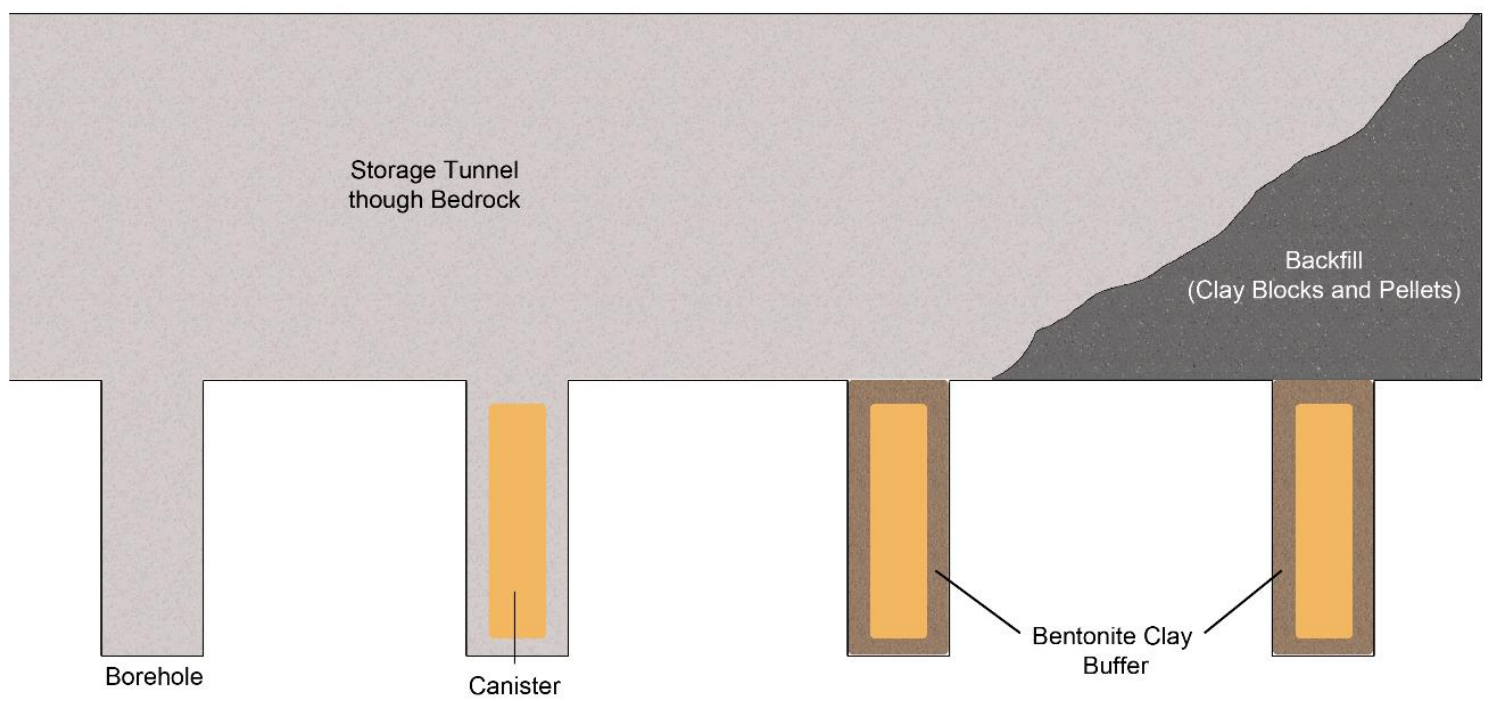

${ }^{*}$ Figure not to scale

Figure 3-1: Crystalline rock with backfill design (e.g., KBS-3) showing one of the many tunnels that consist of the following: canister containing spent nuclear fuel; buffer, which consists primarily of bentonite, a montmorillonite clay; and backfill, which consists of compacted bentonite blocks with surrounding clay pellets.

\subsection{SPENT NUCLEAR FUEL}

The bulk of the fuel that is to be deposited in a KBS-3 repository consists of uranium oxide, which has very low solubility in this repository design environment. If a radioactive substance is not in an oxide form, it must be in a state of similar low solubility to prevent it from dissolving into the groundwater that may penetrate deposited canisters (SKB 2010).

\subsection{CANISTER}

The canister is the structure that contains the spent nuclear fuel and prevents the release of radionuclides into the surrounding environment. The canister serves three major functions: contain the spent nuclear 
fuel and prevent the dispersion of radioactive substances, withstand mechanical loads of the bedrock, and withstand corrosion (SKB 2010).

Design of the canister is cylindrical and consists of a tight copper shell with a load-bearing insert (Figure 3-2). Copper was selected as an outer shell due to its corrosion-resistant properties. However, copper cannot provide the required mechanical strength needed in the final repository. Therefore, a cast iron insert provides sufficient mechanical strength for the canister. All canisters within the repository have the same external dimensions for efficient and cost-effective handling and disposal. Depending on the type of fuel assembly within the canister, different inserts may be required (SKB 2010).

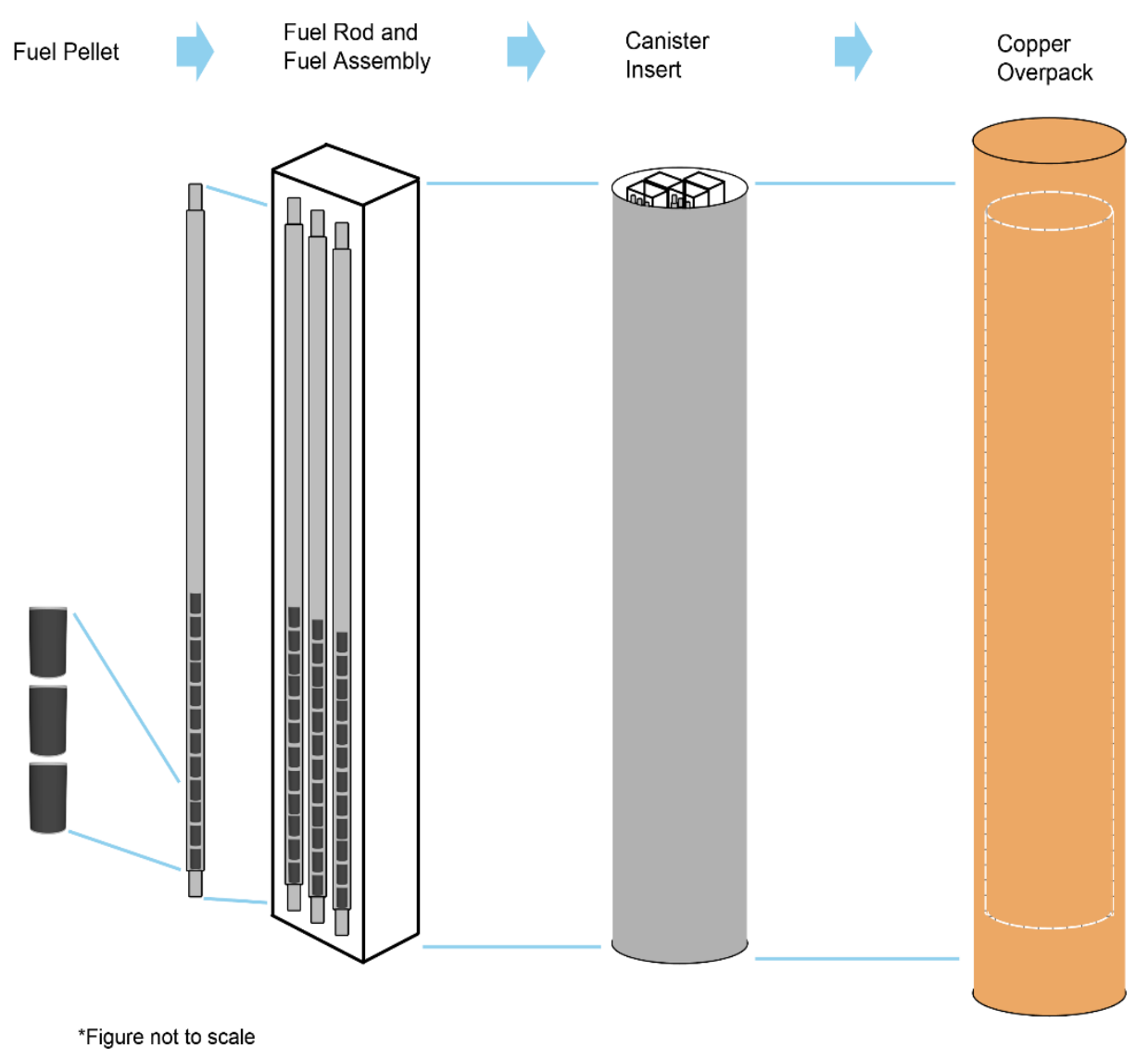

Figure 3-2: Example of fuel rod assembly, canister insert, and copper protective shell of the spent fuel package being deposited.

\subsection{BUFFER}

The buffer material, usually clay, is used as protective material to prevent water flow in the deposition hole and to keep the canister in its centered position (Figure 3-1). In the event of a canister breach, the buffer also prevents and retards the dispersion of radioactive substances into the bedrock. Buffer blocks are also placed on the top of the canister to serve as radiation protection during the backfilling of the tunnel. The buffer clay is usually bentonite, which contains swelling minerals (SKB 2010). Bentonite is a clay formed from the alteration of volcanic tuff, ash, or silica-bearing rocks (granite, basalt) and contains smectite minerals. The major constituent mineral of bentonite clays is montmorillonite. 


\subsection{BEDROCK}

For the KBS-3 design the host rock and geological conditions are important when determining a final repository. The bedrock is crystalline rock such as granite.

\subsection{BACKFILL}

For the KBS-3 design to maintain the multi-barrier principle, backfill is the material used to fill the deposition tunnels. The backfill acts as an additional barrier to limit groundwater flow and to keep the buffer in place by restricting upward swelling and expansion. Backfill material generally consists of compacted bentonite clay blocks and pellets that are then installed in the deposition tunnel (Figure 3-1).

\subsection{UNDERGROUND OPENINGS}

Underground openings refer to the cavities within the bedrock that are required for the subsurface part of the final repository facility. The underground openings do not have any barrier functions, but the locations of the deposition areas and holes are important with respect to the thermal, hydrological, mechanical, and chemical properties of the rock.

\subsection{CLOSURE}

Closure consists of materials installed in investigation boreholes, rock caverns, shafts, ramps, and tunnels that are not deposition tunnels, to fill and close them. The function of the closure material is to not only continue to maintain the multi-barrier principle but to also restrict groundwater flow through the underground openings and to obstruct intrusion into the final repository. Closure material also helps prevent backfill swelling and expansion from the deposition tunnels.

Depending on the section of the repository and type of closure being installed, different geologic materials are used. For investigation boreholes and underground openings where groundwater needs to be restricted, pre-compacted clay is used as a closure material. In the case of underground openings where there needs to be no restriction of groundwater flow, compacted rock material is used. Within the section of repository where underground openings are connected to the surface, the closure consists of closefitting blocks of crystalline rocks to prevent intrusion (SKB 2010).

\subsection{PLUGS}

Plugs are used at the end of deposition tunnels when they are closed and keeps the backfill within the tunnel in place. The plugs also limit the flow of water until the main tunnel has been filled and saturated. However, the plugs have no long-term functions in the final repository.

\subsection{USE CASES}

\subsubsection{Forsmark, Sweden}

In Forsmark, Sweden, spent fuel that is to be deposited in the final repository will mainly consist of fuel assemblies from Swedish boiling light water reactors (BWR) and pressurized light water reactors (PWR). The canisters will be the same size for both spent fuel types, but the cast iron insert will hold 12 assemblies in a BWR insert and four in a PWR insert (SKB 2010).

The bedrock at Forsmark consists mostly of meta-intrusive rocks that formed between 1.89 and 1.85 billion years ago. The bedrock can be separated into four major rock groups (Groups A-D) based on their 
relative age relationships (Table 3-1). Within each group, the bedrock can be further classified into rock units and then rock types (Stephens 2010). Overall, the bedrock at the location of the final repository in Forsmark, Sweden, generally consists of granite and granodiorite based on borehole samples. Granodiorite is similar to granite but contains more plagioclase than orthoclase feldspar. Construction on the Forsmark spent fuel repository is expected to start in the early 2020s.

Table 3-1: Major rock groups with simplified rock units and rock types at Forsmark.

\begin{tabular}{cl}
\hline Rock Groups & \multicolumn{1}{c}{ Rock Units / Rock Types } \\
\hline D & $\begin{array}{l}\text {-Granite, fine- to medium grained } \\
\text {-Pegmatite, pegmatitic granite }\end{array}$ \\
\hline C & -Granite, granodiorite and tonalite, metamorphic, fine to medium grained \\
\hline & -Granite, metamorphic, aplitic \\
\cline { 2 - 2 } & -Granite to granodiorite, metamorphic, medium grained \\
\cline { 2 - 2 } & -Granodiorite, metamorphic \\
\cline { 2 - 2 } & -Tonalite to granodiorite, metamorphic \\
\cline { 2 - 2 } & - Diorite, quartz diorite and gabbro, metamorphic \\
\hline A & -Felsic to intermediate volcanic rock, metamorphic \\
\hline
\end{tabular}

\subsubsection{Olkiluoto, Finland}

The spent fuel repository in Olkiluoto, Finland, is currently active and is considered the world's first permanent disposal site for commercial reactor fuel. It is expected that there will be nearly 3000 sealed copper canisters. Of the Finnish nuclear power plants, there are three different fuel assembly types, but all have widths of $1.05 \mathrm{~m}$ in diameter. The shortest of canisters is from plants Loviisa 1 and 2, while the tallest is from Olkiluoto 3. Canisters from Olkiluoto 1 and 2 are between the other two canister lengths (Posiva 2020).

The overall geologic history of the Olkiluoto area is very complex. The bedrock generally consists of migmatized supracrustal high-grade metamorphic rocks. These typically are migmatized meta-pelites, meta-arenites, and intermediate pyroclastic metavolcanites (Aaltonen et al. 2016). Simply, the main bedrock type is migmatitic gneiss with occurrences of metamorphosed fine-grained sedimentary rock, metamorphosed sand-size grained sedimentary rock, and metamorphosed volcanic rock. 


\section{SALT FORMATION DESIGN}

\subsection{DESIGN CONCEPT}

Salt formations are considered for long-term HLW disposal due to their unique properties of low water content, tectonic stability, and high elasticity (Winterle et al., 2012). While salt has several favorable properties such as low permeability and high visco-elastic creep, its high solubility and low sorption properties can affect storage capabilities in certain settings (Table 1-2). Because rock salt reacts to mechanical loads by creep, cavities within the formation can be "self-sealed" or "healed". Salt formations also exhibit low porosity and are generally impervious to gases and liquids, which are desirable characteristics of a host rock (Winterle et al. 2012).

The typical design of a salt formation spent fuel repository is similar to that of a crystalline rock design in that they are located 400-700 m below ground and have many excavated tunnels (Figure 4-1). In the salt formation repository design, large disposal panels are mined out, with each panel consisting of seven rooms. The panels and rooms are not mined out until waste emplacement due to the fast nature of salt creep. Multiple spent fuel canisters are placed in each room. Once a room is full and sealed, over time, the salt will completely encapsulate the waste, safely isolating it from the environment. In active portions of the mine, long steel bolts and wire mesh are installed into the roof and walls for stability and control of salt creep. The design of the Waste Isolation Pilot Plant (WIPP) in New Mexico, United States, will be discussed further in a later section.

For potential salt formation sites, barrier capabilities of the repository system need to follow and are affected by four design-dependent characteristics: permeability barrier effectiveness, brine/water mobility in the repository near field, waste package integrity, and radionuclide mobility. However, the suitability of any salt formation for geologic disposal of HLWs will depend on its physical and geochemical characteristics. Overall, the salt formation itself is the principal barrier that facilitates waste isolation. In the process of selecting a suitable site, it is important to evaluate the integrity and thickness of the salt formation.

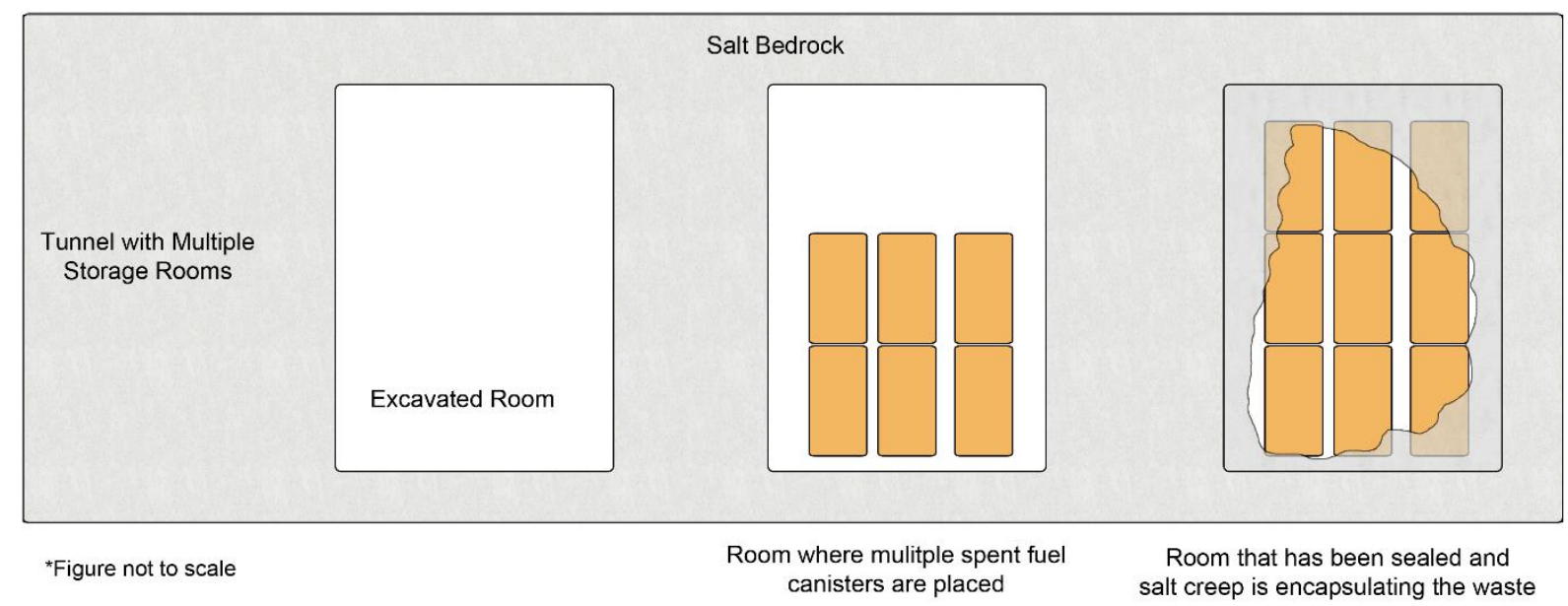

Figure 4-1: Typical tunnel within a spent fuel repository located in a salt formation. Multiple waste containers are placed in an excavated room. Once the room is sealed, over time, salt creep and deformation will encapsulate the waste, isolating it from the environment. 


\subsection{PERMEABILITY BARRIER EFFECTIVENESS}

The extremely low permeability of intact rock salt can prevent water from outside the formation from penetrating into it and fluids trapped inside from migrating out. However, stress changes due to excavated openings and the introduction of a significant heat source from HLW canisters can result in a deformation damage zone around the repository. This damage would enhance permeability in the near field surrounding the emplacement tunnels. Due to creep of the rock salt, the damaged zone would gradually heal over time, but there will likely still be increased porosity in the rock salt. Overall, potential sites need to be evaluated for specific repository design and heat load to ensure the formation is thick enough to handle damage if it may occur (Winterle et al. 2012).

\subsection{BRINE/WATER MOBILITY IN THE REPOSITORY NEAR FIELD}

Existing brine pockets and fluid near the salt formation could contact the waste packages if they are present in sufficient quantity and mobilized by heat or a hydraulic gradient through cracks or fissures. As previously mentioned, deformation due to excavation and heat will likely produce a zone of enhanced permeability. This zone could facilitate movement of fluids around the waste containers. If fluid is present, thermal and hydrological processes can drive the movement of fluid toward the heat source until it reaches a fracture where it would become more mobile. As the waste cools, the deformation zone begins to self-heal over time. However, in the presence of fluid, there still may be a zone with relatively higher, but still low, fluid content surrounding the waste packages (Winterle et al. 2012).

\subsection{WASTE PACKAGE INTEGRITY}

Regardless of fluid mobility within or outside the formation, waste can only be released if waste packages are breached. Corrosion is the primary threat to waste package integrity in a salt repository. Titanium or nickel-chromium alloys are typical materials that are used for containers, but a lead and steel design may be used based on the repository design and geochemical properties of the surrounding bedrock.

\subsection{RADIONUCLIDE MOBILITY}

In the event water contacts the waste and there are existing aqueous pathways through the formation, the mobility of radionuclides determines the magnitude of release to the environment. Radionuclide dissolution and transport outside of the waste package may be impeded by the limed water content and the design of the storage container (Winterle et al. 2012).

\subsection{GEOLOGY}

Salt formations consist primarily of the mineral halite and can include other evaporite minerals (e.g., sylvite, gypsum, anhydrite), carbonates (e.g., limestone, dolostone), and fine-grained siliciclastic sedimentary rocks (mudstone, siltstone, sandstone) (Hovorka and Nava 2000; Winterle et al. 2012). The formation of salt layers, and any sedimentary layers, are deposited horizontally. Some salt layers will remain approximately planar after deposition and are referred to as bedded salt deposits. However, other salt layers develop into diapirs which include salt domes, pillars, and walls (Hovorka and Nava 2000, Winterle et al. 2012).

Salt deformation occurs in response to mechanical stress and a temperature increase. Excavation of an underground opening and heat release from disposed nuclear waste can affect the deformation rate. Creep rate increases with an increase in the magnitude of deviatoric stress and temperature. Disposal openings at WIPP that were initially $4 \mathrm{~m}$ high, $10 \mathrm{~m}$ wide, and $91 \mathrm{~m}$ long underwent a convergence of approximately $30 \mathrm{~cm}$ the first year and 7-13 cm per year thereafter (Chin-Fu et al. 2004; Winterle et al. 2012). 
Salt deformation can either be dilation or compaction. Salt dilation consists of growth and opening of microcracks and pores, which result in an increase in porosity and permeability but a decrease in stiffness and load-bearing capacity (Winterle et al. 2012). Dilation occurs when there is a high ratio between deviatoric and confining stress. Salt compaction consists of the closure of microcracks and pores, which results in a decrease in porosity and permeability but an increase in stiffness and load-bearing capacity. Compaction occurs when the ratio is low between deviatoric and confining stress. Compaction can be associated with healing, while dilation is associated with damage (Winterle et al. 2012). Deformation of the salt bedrock influences waste containers as well. The whole design of a salt repository is for the salt to converge on the containers and isolate them from the environment. The amount of pressure exerted on a container is determined by the depth of overburden along with local heat effects and local stresses. Waste container design is critical to withstand formation pressures.

\subsection{USE CASES}

\subsubsection{Waste Isolation Pilot Plant (WIPP), New Mexico, United States}

While not designed as a spent fuel repository, WIPP permanently isolates non-heat-generating transuranic (TRU) waste $655 \mathrm{~m}$ below ground in an approximately $600 \mathrm{~m}$ thick salt formation. At the repository level, large disposal panels are mined out, with each panel consisting of seven rooms. Each room is $4 \mathrm{~m}$ high, $10 \mathrm{~m}$ wide, and $91 \mathrm{~m}$ long with a $30 \mathrm{~m}$ wall of salt separating each room. Overall, the repository has eight panels, four on each side of the main tunnel.

There are two types of TRU waste that is buried at WIPP. About $96 \%$ of the volume of waste disposed of at WIPP is contact handled $(\mathrm{CH})$. $\mathrm{CH}$ waste primarily emits alpha and beta radiation and is stored in 55-gallon steel drums (DOE 2000). Remote-handled (RH) waste emits gamma radiation that must be handled in lead and steel-shielded transportation containers. $\mathrm{CH}$ waste is typically deposited in an excavated salt room, and bags of magnesium oxide are placed on top of the containers to serve as backfill and to control the solubility of radionuclides (DOE 2020). RH waste can be stored within the rooms as well but in horizontal boreholes within the salt walls. Most of the waste at WIPP are in thin steel drums that are intended to eventually be crushed by the converging salt formation (Winterle et al. 2012). 


\section{VOLCANIC TUFF OPEN AIR DESIGN}

\subsection{GEOLOGY}

The volcanic tuff open air design model is currently being proposed for Yucca Mountain in the United States, and therefore Yucca will be used as the model for this section. Yucca Mountain is located adjacent to the Nevada Test Site in the state of Nevada, in the United States, about $160 \mathrm{~km}$ northwest of Las Vegas and consists of a series of ridges extending $40 \mathrm{~km}$ from Timber Mountain to the Amargosa Desert. The repository would be in a welded volcanic tuff layer (Topopah Spring Tuff) that is approximately 1114 million years old. This rock layer exhibits the proper characteristics of thickness, proximity of faults, mechanical stability to maintain excavated openings, and heat absorption. The water table at this location is approximately $500-800 \mathrm{~m}$ below the surface. The final repository would be located in the unsaturated zone about 200-500 m below the surface and on average $300 \mathrm{~m}$ above the water table. A deep water table and thick unsaturated zone are a result from the slow infiltration rate of surface water due to the dry climate (DOE 2002).

\subsection{DESIGN CONCEPT OF YUCCA MOUNTAIN}

The Yucca Mountain spent fuel repository has a flexible design which gives future generations a choice of either closing and sealing the repository or keeping it open for long-term monitoring as well as adapting to various construction and operational requirements. As stated by a DOE report (2002), the four key aspects of design flexibility are

1. ability of the repository design to support a range of construction approaches,

2. capability to dispose of a wide range of radioactive waste containers,

3. ability to support a range of thermal modes, and

4. ability to continue to enhance the design to best achieve performance-related benefits identified through ongoing analyses.

\subsection{THERMAL MANAGEMENT STRATEGY}

Heat from HLW can affect thermal, hydrologic, chemical, and mechanical processes in the emplacement tunnels and surrounding rocks. In this potential repository, the flexibility of thermal modes can be potentially beneficial. A repository operated at higher temperatures above $100^{\circ} \mathrm{C}$ would dry out the emplacement tunnels and drifts (circular room), which would limit the amount of water available that could contact the waste containers. On the other hand, lower temperatures would cause less disturbance of the local environment near the emplaced waste and hydrologic and geochemical processes in the rock would be less complex than at higher temperatures (DOE 2002). The design of the Yucca Mountain repository would be able to operate and change between both high and low temperature modes.

\subsection{UNDERGROUND FACILITY}

Waste packages would be disposed of in dedicated drifts on emplacement pallets and aligned end-to-end on the drift floor (Figure 5-1). If the facility is in a high-temperature operating mode, packages would be spaced about $10 \mathrm{~cm}$ apart. In low-temperature operating mode, several waste package and drift spacings are being evaluated. The facility would include 58 horizontal emplacement drifts that are $5.5 \mathrm{~m}$ in diameter with a center-to-center drift spacing of $81 \mathrm{~m}$. The underground facility would take up approximately 1150 acres. When emplacing the waste packages, they would be moved one at a time from the surface to the drifts by a connecting rail system. Before the repository is permanently closed, overlapping and interlocking drip shields (Figure 5-1) would be placed over the packages to divert any potential water that may drip from the top of the drift (DOE 2002). 


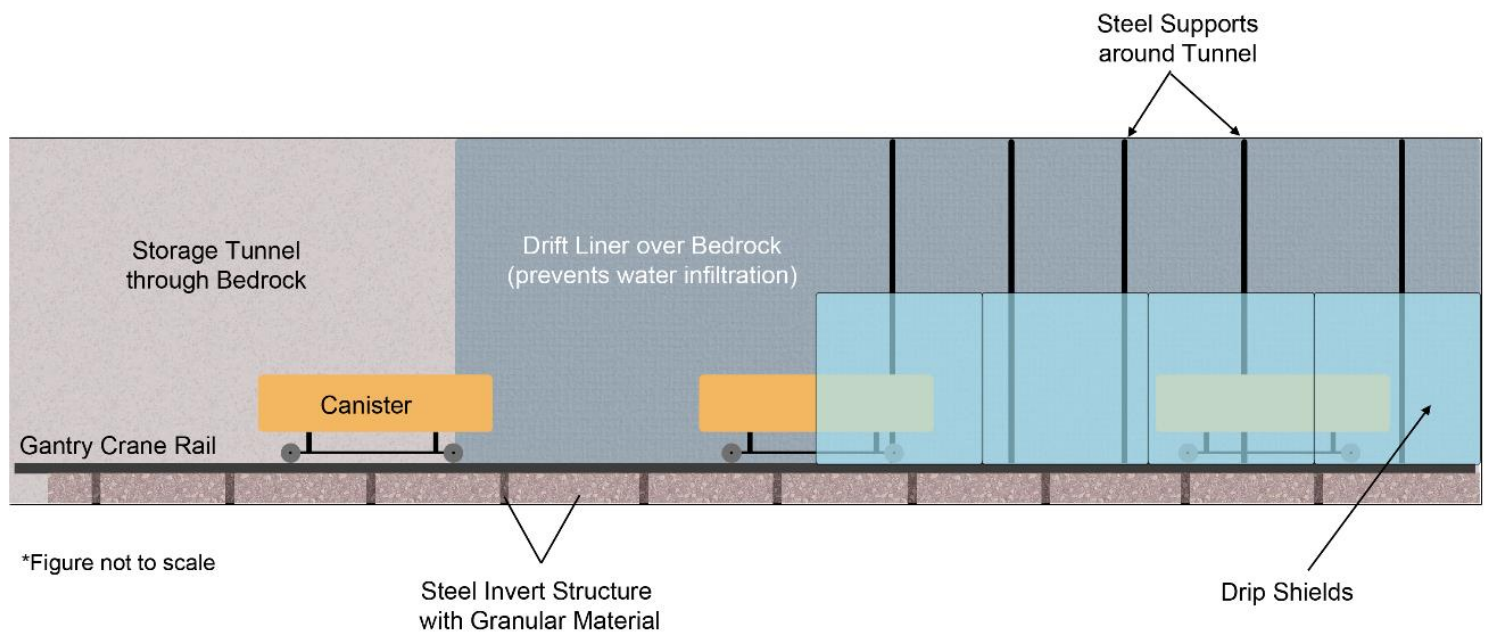

Figure 5-1: Volcanic tuff open air design (e.g., Yucca Mountain) where canisters containing spent fuel are aligned end-to-end on the drift floor. Granular material is located beneath the rail as a protective buffer material. A drift liner and drip shields are present to divert any water that may enter the drift.

\subsection{NATURAL BARRIERS}

Natural barriers at Yucca Mountain include surface soil, unsaturated rock layers above and below the repository, and volcanic tuff and alluvial deposits below the water table. These barriers are important as they isolate the waste, limit the amount of water entering the emplacement drifts, and limit the transport of radionuclides through the environment. The surrounding bedrock (Topopah Spring Tuff) has a maximum thickness of $375 \mathrm{~m}$ (DOE 2002).

As previously mentioned, the bedrock can sustain excavated tunnels and absorb any heat generated by waste packages. However, in this welded tuff layer, fractures are present which are dominant pathways for water to flow in both the unsaturated and saturated zones. The design of the final repository would take advantage of the fractures and free-draining nature of the host rock, which would promote the flow of water past the emplaced waste and limit water availability to the waste packages. The water table below the proposed repository is located in the Calico Hills Formation and Crater Flat Group, which are less fractured. The Calico Hills Formation also contains an abundance of zeolite minerals, which have the ability to sorb radionuclides that might be transported in solution in water through the fractures (DOE 2002).

\subsection{ENGINEERED BARRIERS}

Components of the engineered barriers are designed to complement the natural barriers in isolating the waste packages. The design of the repository's engineered barriers includes the waste package, waste form, drip shield, and the emplacement drift invert (supporting structures) (Figure 5-1). Overall, engineered barriers contribute to waste isolation by using long-lived waste packages, using drip shields to divert water away and limit the release of radionuclides (DOE 2002).

\subsection{WASTE PACKAGES AND WASTE FORM}

The waste package would have a dual-metal design with two concentric cylinders. The inner cylinder would be made of stainless steel $316 \mathrm{NG}$, and the outer cylinder would be nickel-based alloy 22 . The alloy 22 would protect against corrosion, while the inner steel cylinder would provide structural support (DOE 2002). 
Materials deposited would include spent nuclear fuel and vitrified HLW, both which are in solid form. These materials will degrade very slowly in the Yucca Mountain environment. Spent nuclear fuel primarily consists of heavy metal oxides (e.g., uranium, plutonium). HLW consists of vitrified borosilicate glass containing radionuclides (DOE 2002).

\subsection{DRIP SHIELDS AND DRIFT INVERT}

Drip shields are a major component of the engineered barrier system (Figure 5-1). They are installed over the waste packages prior to repository closure. The function of drip shields is to divert any moisture that may drip from the drift walls, ceilings, and condensed water vapor around the waste packages. Drip shields would be of a standard size as they are to be used with all waste package types and made from titanium to provide corrosion resistance and structural strength (DOE 2002).

Drift invert includes the structures and materials that support the pallet, waste package, rail system, and drip shield. It is composed of a steel invert structure and a ballast that consists of granular material. Upon closure, the granular material provides a layer below the waste packages that would slow the movement of radionuclides into the bedrock (DOE 2002). 


\section{CLAY OR SHALE FORMATION WITH BACKFILL}

\subsection{GEOLOGY}

Many countries such as France, Switzerland, Belgium, Japan, and Canada are considering the use of argillaceous (high clay content, clay-size materials) formations as a potential host rock for disposal and containment of their nuclear wastes (Hendry et al. 2015). Argillaceous formations are being considered due to their low permeability and high sorption capacity in respect to radioactive wastes and other hazardous materials (Deniau et al. 2007; Hendry et al. 2015). These formations are located throughout the world as surficial deposits (e.g., glacial tills or glacio-lacustrine deposits) or consolidated or unconsolidated units within sedimentary basins (e.g., mudstone, claystone, shales) (Hendry et al. 2015).

\subsection{USE CASES}

\subsubsection{Haute-Marne, France (Cigeo Project)}

The Cigeo deep geological repository in France is designed for the disposal of high- and intermediatelevel long-lived radioactive waste (HLW and ILW) while adhering to the French requirements of reversibility (Gaussen and Andra 2005; Labalette et al. 2013). It will be constructed in the 160 millionyear-old Callovo-Oxfordian argillite formation within the Paris Basin (Stavropoulou et al. 2020). This low permeability formation starts at a depth below the surface of $420 \mathrm{~m}$ and ends at approximately $600 \mathrm{~m}$. Thickness varies throughout the formation between 130-160 m (Gaussen and Andra 2005).

The disposal facility would consist of disposal cells excavated in the argillite formation which would contain the waste packages. The repository would have sections based on the type of waste being disposed of (e.g., HLW, ILW). HLW would be disposed of in lined horizontal tunnels extending from the main access drifts (tunnels). The layout of the repository and process is similar to the KBS-3 design in that after the waste packages are emplaced in the tunnels, they are overpacked with bentonite or similar clay (Labalette and Hoorelbeke 2011). The Cigeo Project is currently pending and will tentatively start in the mid 2020s. 


\section{CONCLUSION}

Based on the above findings, the four deep geological storage designs will be considered in small-scale laboratory tests - crystalline bedrock with bentonite backfill (KBS-3), salt formation (WIPP), volcanic tuff open air design (Yucca), and clay formation with backfill (Cigeo). All four designs are located within deep bedrock layers. Bedrock types for KBS-3 and Yucca designs are either igneous or metamorphic, whereas the salt design is located within a sedimentary salt layer. The Cigeo design is located within a sedimentary layer. The crystalline rock, salt formation, and clay formation designs make use of emplacement drifts with either rooms or boreholes for the spent fuel canisters. What makes them different are that KBS-3 (vertical emplacement tunnels) and Cigeo (horizontal emplacement tunnels) rely on buffer and/or backfill material (typically bentonite clay) for sealing, while the salt design depends on the unique deformation properties of salt to encapsulate the waste. The volcanic tuff open air design, while not currently implemented, is unique in that the canisters are emplaced in an open room environment which can be controlled, depending on the type of waste.

For small-scale laboratory designs, a modular design was chosen for the ability to reconfigure tunnels and rooms as needed. Standard 6-in. concrete construction blocks are chosen to simulate boreholes and emplacement rooms, while solid concrete construction blocks are used to represent the surrounding bedrock material. Bentonite clay is used for the buffer and backfill material like the KBS-3 design. To approximately simulate the geological properties of a salt layer, while considering the availability of materials, salt blocks can be used to represent an excavated room within the layer. 


\section{RESOURCES}

Aaltonen, Ismo; Engström, Jon; Front, Kai; Gehör, Seppo; Kosunen, Paula; and Kärki, Aulis. 2016. Geology of Olkiluoto. Posiva Working Report 2016-16. Vol. 31.

Chin-Fu, Tsang; Bernier, Frederic; and Davies, Christophe. 2004. "Geohydromechanical Processes in the Excavation Damaged Zone in Crystalline Rock, Rock Salt, and Indurated and Plastic Clays." International Journal of Rock Mechanics and Mining Sciences.

Deniau, I.; Devol-Brown, I.; Derenne, S.; Behar, F.; and Largeau, C. 2007. "Comparison of the bulk geochemical features and thermal reactivity of kerogens from Mol (Boom Clay), Bure (CallovoOxfordian argillite) and Tournemire (Toarcian shales) underground research laboratories." Science of the Total Environment, 389:(2-3): 475-485. doi: 10.1016/j.scitotenv.2007.09.013

DOE. 2000. Three Types of Containers Container Waste Type Status of Certification Transuranic Waste Transportation Containers.

DOE. 2002. Yucca Mountain Science and Engineering Report: Technical Information Supporting Site Recommendation Consideration.

DOE. 2020. "U.S. Department of Energy's Waste Isolation Pilot Plant - Waste Panels and Capacity." Accessed January 28. https://wipp.energy.gov/waste-panels-and-capacity.asp.

Gaussen, JL./Andra. 2005. GEOLOGICAL REPOSITORY LAYOUT FOR RADIOACTIVE HIGH LEVEL LONG LIVED WASTE IN FULL PAPER.

https://www.laradioactivite.com/site/pages/RadioPDF/GAUSSEN.pdf.

Hendry, M. J.; Solomon, D. K.; Person, M.; Wassenaar, L. I.; Gardner, W. P.; Clark, I. D.; Mayer, K. U.; Kunimaru, T.; Nakata, K.; and Hasegawa, T. 2015. "Can argillaceous formations isolate nuclear waste? Insights from isotopic, noble gas, and geochemical profiles." Geofluids, 15(3), 381-386. https://doi.org/10.1111/gfl.12132.

Hovorka, S., and Nava, R. 2000. Characterization of Bedded Salt for Storage Caverns - A Case Study from the Midland Basin, Texas.

IAEA, 2009. Geological Disposal of Radioactive Waste: Technological Implications for Retrievability. IAEA Nucl. Energy Ser. No. NW-T-1, 1-64.

Labalette, T., and Hoorelbeke, J. M. 2011. "Cigeo Project Industrial Geological Repository Project.” Blue Ribbon Commission Visit Presentation. Andra. Web. https://cybercemetery.unt.edu/archive/brc/20120621063907/http:/brc.gov/sites/default/files/meeti ngs/presentations/cigeo_project.pdf.

Labalette, T.; Harman, A.; Dupuis, M. C.; and Ouzounian, G. 2013. "Cigeo, the French Geological Repository Project - 13022.” OSTI. Web. https://www.osti.gov/biblio/22224830-cigeo-frenchgeological-repository-project.

Posiva. 2020. "Basics of the Final Disposal - Posiva." Accessed January 23. http://www.posiva.fi/en/final_disposal/basics_of_the_final_disposal\#.Xim4YGhKhaQ.

SKB. 2010. Design and Production of the KBS-3 Repository. Design and Production of the KBS-3 Repository Technical Report TR-10-12.

Stephens, M.B., 2010. "Forsmark Site Investigation. Bedrock Geology - Overview and Excursion Guide.” SKB Report, no. September: 52.

http://www.iaea.org/inis/collection/NCLCollectionStore/_Public/41/134/41134044.pdf. 
Stravropoulou, E., Briffaut, M., Dufour, F., Camps, G., 2020. “Time-dependent behavior of the CallovoOxfordian claystone-concrete interface". Journal of Rock Mechanics and Geotechnical Engineering. 12(1):89-101. https://doi.org/10.1016/j.jrmge.2019.09.001

Winterle, J, G Ofoegbu, R Pabalan, C Manepally, T Mintz, E Pearcy, K Smart, J Mcmurry, and R Pauline. 2012. "GEOLOGIC DISPOSAL OF HIGH-LEVEL RADIOACTIVE WASTE IN SALT FORMATIONS Prepared for Center for Nuclear Waste Regulatory Analyses San Antonio, Texas U. S. Nuclear Regulatory Commission”.

World Nuclear Association, 2018, Storage and Disposal of Radioactive Waste. https://www.worldnuclear.org/information-library/nuclear-fuel-cycle/nuclear-waste/storage-and-disposal-ofradioactive-waste.aspx 